\title{
Resilience of social-ecological systems: drastic seasonal change is associated with economic but not social flexibility among fishers in the Brazilian Pantanal
}

\author{
$\underline{\text { Rafael M. Chiaravalloti }}^{1,2,3}$, Daniel M. Freitas $^{4}, \underline{\text { Rodrigo A. de Souza }}^{5}, \underline{\text { Sumalika Biswas }}^{1}, \underline{\text { Andrea Markos }}^{6}, \underline{\text { Miraira Noal Manfroi }}^{7}$
} and Mark Dyble ${ }^{8}$

\begin{abstract}
In attempting to predict the impact of major ecological or climatic change on livelihoods, insights can be gained by looking at communities who experience extreme seasonal or annual variation. Here, we compare the ecology, economy, and social network of a community of traditional fishers in the Brazilian Pantanal between the dry season and the flood season in which their wetland ecosystem is transformed. Using data derived from satellite imaging we show that during the flood season of 2019 the total amount of open water accessible to fishers more than doubled and led to drastic qualitative changes. We show that although fishers adapted to this extreme seasonality by changing where, how, and what they fish between seasons, the structure of the social network in our study community did not differ. We argue that strong networks are especially important in social-ecological systems with extreme seasonal changes. More generally, we suggest that case studies of seasonal adaptation such as ours can contribute to a broader understanding of how communities may be able to successfully adapt to novel social-ecological changes.
\end{abstract}

Key Words: fisheries; resilience; social-ecological systems; socio-networks; the Pantanal

\section{INTRODUCTION}

Understanding the resilience of local communities is a crucial part of sustainability science (Linkov et al. 2014) and is vital if we want to predict how habitat loss (Lewis and Maslin 2015, IPBES 2019), climate change (IPCC 2018), large infrastructure projects (Winemiller et al. 2016), and agrarian change (Borras and Franco 2012) are likely to affect the millions of small-scale communities whose livelihoods depend directly on natural resources. Such communities protect over $25 \%$ of global ecosystems (Garnett et al. 2018) and at least $36 \%$ of the intact forest landscapes (Fa et al. 2020). One of the major barriers to this understanding, however, is our limited knowledge of how different aspects of resilience play out on the ground in face of environmental change (Clark and Harley 2019).

Community resilience can be achieved either through the process of adaptation, which allows the community to retain the same function, structure identity and feedback despite ecological change (Walker et al. 2004) or through a process of transformation in which the community modifies their way of life when ecological change makes the existing system unsustainable (Folke et al. 2010). Adaptation and transformation are usually achieved through changes in economic behavior, social organization, and institutional arrangements. For example, the ability to engage flexibly in wage-labor, trading, and other activities has been argued to be important in allowing some communities of Agta foragers in the northern Philippines to maintain their livelihood in the face of reduced hunting and fishing returns (Minter 2010, Dyble et al. 2019). Similarly, previous experience with alternative economic activities appears to be a key factor in determining whether communities are able to avoid economic "lock-ins" in the face of the increased frequency of El Niño events in the Global South (Whitfield et al. 2019). In the social domain, the ability to change group size and composition is often an important part of resilience. For example, pastoralists in northern Mongolia re-group every 5 to 10 years after facing extreme winter storms, and later disperse again (Clark and Crabtree 2015). Similar "multilevel" or "fusion and fission" patterns have been described for many pastoralist and forager societies and play an important role in adapting to seasonal change (Kelly 2013, Thomas et al. 2015, Dyble et al. 2016, Bird et al. 2019). Some authors consider robustness (the ability to maintain the characteristics of the systems in of face of external or/and internal drivers of change) as part of resilience (Levin and Lubchenco 2008)

The ability of a community to adapt or transform their way of life also depends on existing cultural norms and social structure. Even if we are to consider individuals to be rational actors who try to maximize economic returns, most will be attempting to do so as part of social groups (Monk et al.2018) and access to natural resources is often mediated by friendship, status, age, and historical relationships and privileges (Ribot and Peluso 2009). In addition to this, de jure institutions may either reinforce or override what has been negotiated on the ground, changing the way people adapt, transform, or maintain their social-ecological system (Benjaminsen and Lund 2002). The relationship between local institutional arrangements and state institutions often determines the success of adaptation or transformation (Robinson et al. 2018).

\footnotetext{
${ }^{1}$ Smithsonian Conservation Biology Institute, Conservation Ecology Center, Virginia, USA, ${ }^{2}$ Imperial College London - Center for Environmental Policy, ${ }^{3}$ IPE - Institute of Ecological Research, ${ }^{4}$ IBAMA, Brazilian Institute of Environment and Renewable Natural Resources, Brasília - DF, Brazil, ${ }^{5}$ National Center for Monitoring and Environmental Information from Brazilian Institute of Environment and Renewable Natural Resources, CENIMA/IBAMA, Brasília - DF, Brazil, ${ }^{6}$ Academia Nacional de Ciencias de Bolivia, Santa Cruz de la Sierra, Bolivia, ${ }^{7}$ Federal University of Santa Catarina, Florianópolis-SC, Brazil, ${ }^{8}$ Department of Anthropology, University College London, London, UK
} 
Despite these complexities, many management interventions aimed at ensuring the sustainability of resource-dependent communities are still focused on relatively simplistic approaches (Ostrom 2007, Wilson 2017). In the management of inland fisheries, for instance, management strategies are focused on catch statistics and intake and outtake policies based on models of single species used by a homogenous group (Allan et al. 2005) and that ignore the presence of recreational fisheries, dispersed landings, diversity of fishing gear, and livelihoods, mobility, and seasonal changes (Cowx et al. 2004), creating a mismatch between local social-ecological dynamics and external interventions (Cooke et al. 2016). The examples, in fact, go beyond inland fisheries, encompassing mobile pastoralists (Derry and Boone 2010), swidden cultivators (Dressler et al. 2010), farmers, huntergatherers (Pyhälä et al. 2019), among others. Evidence shows that management strategies that are not in tune with local dynamics can an increase marginalization, gender inequality, food insecurity, morbidity and mortality, social disarticulation, and even the contravention of human rights through violent eviction or/and environment impact (Sikor and Lund 2009). A better understanding of resilience dynamics is therefore important both in reaching sustainable development goals and advancing the international environmental and development agenda more generally (Griggs et al. 2014).

Here, we sought to understand economic and social responses to marked seasonal variation among a community of fishers living in the Pantanal wetland. Our study community, Barra do São Lourenço, inhabit an environment in which annual floods and stochastic vegetation movements completely transform the environment each year and make the location of productive fishing sites highly unpredictable both within and between seasons and years (Chiaravalloti 2019). We quantified seasonal differences in the ecology, fishing practices, and social networks of the Barra do São Lourenço community, providing a quantitative case study of how this community responds to ecological changes.

\section{METHODS}

\section{Study area}

The Pantanal wetland, located in the center of South America and largely in Brazil, is the largest and most conserved wetland in the world, covering $17,930 \mathrm{~km}^{2}$ and with $80 \%$ of its original vegetation still standing (Junk et al. 2006). Recently, however, the region has seen a growing threat from infrastructure projects, intensification of cattle ranching, and wildfires that, in 2020, devastated the Pantanal, destroying an estimated $30 \%$ of the total biome (Tomas et al. 2019, LASA 2020).

\section{The Barra do São Lourenço community}

Our study community is the Barra do São Lourenço fishing community, located around $150 \mathrm{~km}$ north of the port town of Corumbá, Brazil. With a total population of 16 households (95 people), they have strong Amerindian roots, but have also assimilated migrants who came to the region during waves of colonization or social change, including formerly enslaved peoples and Paraguayans. Today, members of this community, regardless of ancestry, carry a distinct identity, referring themselves as "ribeirinhos": those who fish and live by the river (Chiaravalloti 2019). According to the Brazilian National Policy for Sustainable Development of Traditional Peoples and Communities (decree number 6040, 2007), they are categorized as a "traditional people," which, in principle, legally guarantees tenure rights to their traditional territory (Almeida and Silva 2012).

Fishing is the main livelihood of up to $80 \%$ of the households (Chiaravalloti 2019). Fishing is mainly focused on two species of catfish, pintado (Pseudoplatystoma corruscans) and cachara (Pseudoplatystoma reticulatum), and one species of scaly fish pacu (Piaractus mesopotamicus); together they represent over $80 \%$ of all catch in the region (Catella et al. 2014). Local people also gather bait for sport fishing tourists, mainly a small lungfish named tuvira (Gymnotus spp.) and the Pantanal crab (Dilocarcinus pagei; Costa and Lucato 2000). Although local people fish for their own consumption, the majority of their catch is sold to middlemen or in the city of Corumbá and they are therefore best classified economically as being small-scale commercial fishers (Catella et al. 2014; Fig 1).

Fig. 1. The location of Barra do São Lourenço community with the boundaries of their territory.

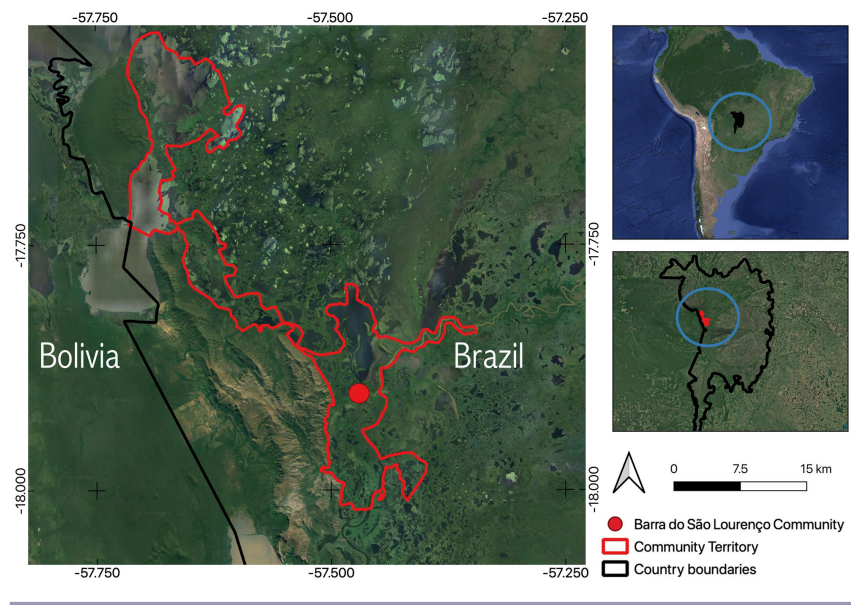

Ecological dynamics

The availability and distribution of natural resources in the Pantanal is dictated in large part by the annual flood pulse (Junk et al. 2011). Because of the slight gradient of the terrain in the Pantanal (2-3 cm/km north to south; $5-25 \mathrm{~cm} / \mathrm{km}$ east to west) the flood pulse takes 3-4 months to pass through (Junk et al. 2006). The extent and duration of the annual floods in the region may change depending on a combination of precipitation, water flow, and drainage in the surrounding highlands. Across years, the total flooded area can vary by an order of magnitude, from approximately $11,000 \mathrm{~km}^{2}$ to $110,000 \mathrm{~km}^{2}$ (Hamilton et al. 1996).

For small-scale pantaneiro fishers, the location of fish or bait during and after the flood pulse is highly uncertain because fishing or gathering grounds are typically only accessible and profitable for a few days because of the moving flood pulse and the presence of floating vegetation mats whose movements regularly block or open water bodies in an unpredictable way (Pott et al. 2011, Chiaravalloti 2017a). As a further complication, the Barra do São Lourenço community is located close to the confluence of two 
large rivers (Paraguay and São Lourenço rivers) that differ markedly in hydrology, enhancing the already unpredictable nature of the biodiversity distribution and availability (Chiaravalloti 2017b, Chiaravalloti and Dyble 2019).

\section{Governance and institutional arrangements}

Previous studies in the Pantanal have shown that the governance system of fishers from the Barra do São Lourenço community should be classified as a hybrid between open property and common property regimes, named "limited open access" (Chiaravalloti and Dyble 2019). In this system, fishers survive by sharing information about productive fishing or bait gathering locations. This information is shared and discussed during ice-tea drinking sessions (tereré). Within the communities there is no territoriality and fishers from the same community can come and fish on the same lake that some else is already using. Therefore, between community members, there are no defined boundaries around the resources that they use, as predicted in open property regimes (Moritz et al. 2018). We have previously argued that the openness and reciprocity that occurs within the Barra do São Lourenço community is the unpredictable availability of natural resources in the region explained above, which forces people to find cooperative ways to increase their chance of finding fish or bait (Chiaravalloti and Dyble 2019). However, neither information nor fishing grounds are shared with people from outside Barra do São Lourenço (Chiaravalloti 2017a). The community has a clear territory that they will defend if fishers from other communities trespass its limits. For example, ethnographic research has recorded several knife fights with people from other communities trying to fish within Barra do São Lourenço territory (Chiaravalloti 2017a). Theoretical models suggested that limiting the sharing of information and territory to community members results from a compromise between the benefits of information sharing and the costs of competition (Chiaravalloti and Dyble 2019). Therefore, between communities, the system has features that are usually characteristic of a common property regime (Ostrom 1990).

\section{Data collection}

We have been studying the Barra do São Lourenço community since 2013, and have conducted eight one-month field trips between 2013 and 2014 as part of an ethnographic study by RC (Chiaravalloti 2019) and 10 two-week field trips as part of a longterm project focused on livelihood changes and persistence between 2015 and 2019. The project was approved by both a federal and a local ethics committee from the study region (acceptance number CAE 828,070).

\section{Spatial data}

Spatial data were used to estimate water availability in 2019 for a period of the dry (7 March to 6 April) and flood seasons (6 June to 6 July) for a 3-km radius around the Barra do São Lourenço community. For each season we first estimated the total area of water using Sentinel 1 (radar, 5 meters resolution). These images are not blocked by any kind of vegetation or cloud, which allows us to estimate the total quantity of water in the system regardless of the presence of aquatic vegetation or gallery forest blocking the visualization. Second, based on the data on "water," we created a hybrid image combining both Sentinel 1 (radar) and Sentinel 2 (optical, also 10 meters resolution). Sentinel 2 (optical) allows us to measure only the visible water in the system. In this case,
Sentinel 2 does not capture water hidden by the aquatic vegetation. Therefore, a hybrid image of Sentinel 1 and 2 allowed us to measure the quantity of water that is not hidden under the aquatic vegetation, "open water." Several processing tools were used to produce these hybrid images, including the calibration of a different Normalized Difference index (such as Normalized Difference Water Index) based on photos of the area from the same time, cloud and temporal filtering, and visual inspection. The classification was carried out through random forest based on 100 random trees. We developed this method of flood classification based on Xu (2006) and Huang and Jin (2020). We also created a map of water connectivity, which is the total surface area of water that was not covered by vegetation and that was accessible by boat from the main river, named here "accessible open water." This was created through a morphological pattern analysis, based on a method developed by Soille and Vogt (2009). The final result was a raster showing water bodies connected to the main river. This analysis was conducted in QGis 3.0, MSPA plugin (Vogt and Riitters 2017). The models were tested by comparison with GPS data from the field to test for accuracy.

\section{Economic data}

We collected data on the livelihood strategies and fishing returns of all community households using two methods: calendars and semi-structured interviews. The calendars consisted of 30 daily sheets that included a map of the region and illustrations of the fish or bait that fishers in the community might catch. We provided one calendar to each of the 16 households during the dry season (7 March to 6 April) and another during the flood season (6 June to 6 July). We asked them to note their daily catch, to indicate on a map where they had gone fishing, and to mark whether they have not gone fishing for some reason, e.g., resting day, religion reasons, celebrations, etc. During the first week of the calendar we visited each of the 16 households on at least two occasions to help them to fill out the calendar. Before we left the community, we asked all households to fill them out themselves every day after they returned from fishing. The same method was repeated in the dry and flood seasons. Similar citizen science techniques in the Barra do São Lourenço community have been used since 2013, and community members already have experience in helping to collect scientific data (Chiaravalloti 2017a). We also interviewed all households both during the dry and flood season through the semi-structured interviews. First, we aimed to double-check some of the information provided in the calendars, repeating some of the questions to check information reliability. Out of the 16 households asked to fill out the calendars, eight returned them in both seasons and with the answers considered reliable. We also recorded the type of fishing gear and bait used, fishing techniques, and other possible differences in fishing practices between seasons. We converted daily catch into a monetary value (in Brazilian Reais) based on the average price paid in the nearest city for each species at that time (Catella et al. 2014).

\section{Social network data}

People in the Barra do São Lourenço community frequently visit each other to discuss productive fishing locations and rely on the information that they share. We sought to capture these interactions using a roster method in which adults from each of the 16 households were asked if they had spoken about fishing grounds to members of each other household within the last two weeks. By using a list of all households as a prompt during 
interviews, this method reduces the likelihood of recall errors (Butts 2008). This information was used to build social networks. In building these networks we only included dyads with mutual agreement, i.e., where $A$ reported speaking with $B$ and $B$ reported speaking with $A$. To establish kinship between community members, we conducted genealogical interviews with all adults in the community and, from this, built a network of relatedness for all community members defined according to a measure $(s)$ that takes into account both affinal and consanguineal relatedness (Dyble et al. 2018). We looked at two measures of overall social network structure: average path length and transitivity. Average path length measures the mean number of ties between pairs of individuals across the whole network. Transitivity is a measure of how clustered interactions are. Statistical analyses were performed in R.3.3.3 (R Core Team 2018), and network analysis and visualization used functions from the igraph package (Csardi and Nepusz 2006). Permutation tests were conducted using a custom script with 10,000 permutations.

\section{RESULTS}

\section{Seasonal ecosystem changes}

Our satellite imaging results demonstrate the marked seasonal change in the ecology of the Pantanal associated with the annual flood pulse (Fig. 2). During the dry season the 3605 ha area around Barra do São Lourenço included a total of 1453 ha of surface water. Of this, 714 ha was open, i.e., not covered by vegetation, and 456 ha was both open and accessible to fishers. For the same area in the flood season, 1932 ha was surface water of which 1029 ha was open and 977 ha was both open and accessible. Thus, the amount of water available to fish during the flood season was more than double that of the dry season (453 to 977 ha, a $214 \%$ increase). If we exclude the large River Paraguay from these estimations and look only at the smaller channels and pools in which fish are most often found at high density, the difference is even more pronounced, with 182 ha accessible in the dry season versus 703 ha accessible during the flood.

\section{Economic changes}

Our economic data show differences in catch composition, fishing techniques, and space use between the dry and flood seasons. In the dry season, fishers reportedly focused their efforts on using multiple fishing rods fixed into the riverbank (anzol de galho) to catch large migratory fish (mostly catfish), which are concentrated in the main channels migrating up the river during this period. In contrast, in the flood season fishers changed their focus to short migratory fish (scaly fish), which are concentrated in smaller water bodies during this period. Because there are no riverbanks to fix the rods to during the flood, local people started to use fly fishing (batida) from their canoes or small boats (Fig. 3). These seasonal differences can be seen in our data (Fig. 3a), with catfish contributing more to the total catch by monetary value in the dry season $($ dry $=51.1 \%$, flood $=20.1 \%)$ and scaly fish contributing more in the flood season $(\mathrm{dry}=10.8 \%$, flood $=37.9 \%)$. Bait gathering was an important part of the total catch in both seasons $($ dry $=38.1 \%$, flood $=41.9 \%)$.

Our data also show that fishers were more mobile during the flood, with fishing trips by the same people on consecutive days being $\sim 50 \%$ more likely to be made to different areas during the flood compared with the dry season (dry: $\mathrm{N}=80$ fishing trips, $45.0 \%$

Fig. 2. Seasonal variation in accessible water for fishing in the Pantanal. The first row refers to the images from the dry period ("water": all water in the system; "open water": all water that is not covered by aquatic vegetation; and "accessible open water": all water bodies that are not covered by aquatic vegetation and can be accessed by boat from the main river. The second row refers to the images from the flood period, also showing the three "water" types.

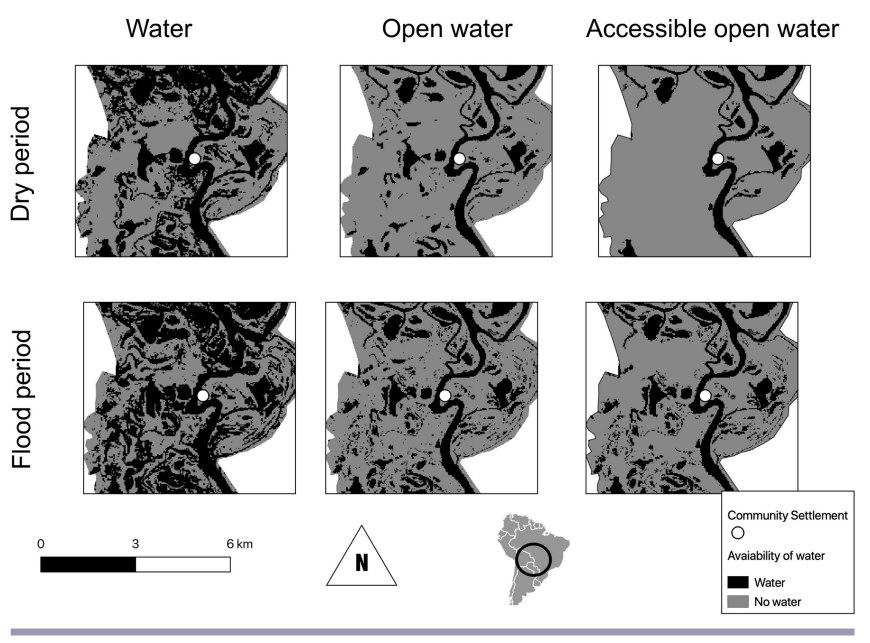

Fig. 3. Seasonal changes in fishing practices and return rates. (a-b) Catch composition in the dry and flood season, divided into three main categories (from left to right): bait, catfish, scaly fish; (c) probability of fishers moving area from one day to the next in each season; (d) daily fishing returns in each season.

(a)

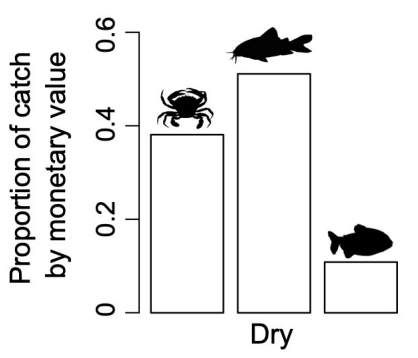

(c)

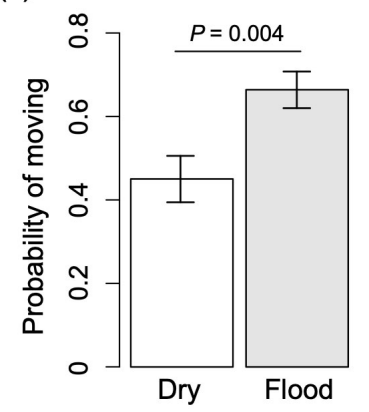

(b)

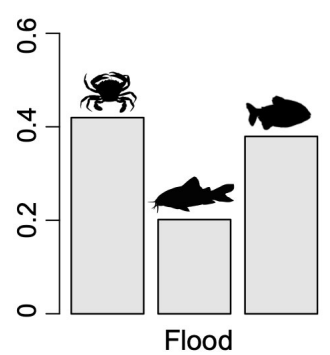

(d)

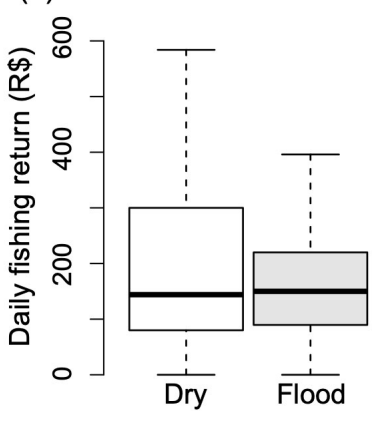


fishers moved from one day to the next $95 \% \mathrm{CI}=[39.4,50.56]$; flood: $\mathrm{N}=116$ fishing trips, $66.4 \%$ fishers moved from one day to the next $95 \% \mathrm{CI}=[62.0,70.8]$, proportions test $X^{2}=8.01, \mathrm{p}=$ 0.005 ; Fig. 2b). During the dry season, the majority of fishing was concentrated in two areas close to the home settlement, while in the flood season fishing ranged across a broader area, with some overnight trips into the northern part of the region, around $50 \mathrm{~km}$ from home. The seasonal flexibility we see in how, where, and what the Pantaneiros fish allows them to maintain similar fishing return rates between seasons despite the ecological differences (dry season: $\mathrm{N}=91$ fishing trips, mean $=\mathrm{R} \$ 201$, $\mathrm{SD}$ = 168; flood: $\mathrm{N}=142$ fishing trips, mean $=\mathrm{R} \$ 168, \mathrm{SD}=122$; Fig. 3b).

\section{Social changes}

Despite the pronounced differences in fishing methods and space use between seasons, the overall social network was very similar across the two fishing periods (Fig. 4a-b). The overall proportion of households that had spoken to one another during the previous two weeks was $~ 50 \%$ in both fishing seasons (March: 118 of 240 ties [49.1\%], August: 122 of 240 ties [50.83\%]) and the overall structure of the network was also similar in both fishing seasons (March: average path length $=1.54$, transitivity $=0.55$; August: average path length $=1.49$, transitivity $=0.58$ ). However, this similarity occurred despite a large turnover in who people interacted with. If two households interacted in the dry season, there was a $59.3 \%$ chance they interacted in the flood season. Although a permutations test suggests that this is significantly more consistent than expected by chance (expected $=50.9 \%, \mathrm{p}=$ 0.027 ), the magnitude of the effect is small, suggesting that interactions in August are only $\sim 15 \%$ more likely to occur if they also occurred in dry season than would be expected if interactions were random. In fact, the consistent ties in the network appear to be largely among closely related households (related by $\mathrm{s}>0.25$, see Methods) such that when these closely related households are excluded from the network the remaining interactions are no more likely to be seen across seasons than by chance (observed consistency $=39.7 \%$, expected $=41.2 \%$, two-tailed permutation test $\mathrm{p}=0.45$ ). However, although households varied greatly between seasons in who they interacted with, there was consistency in the overall number of interactions they had, with a significant correlation in the number of interactions each household has across seasons (Pearson's $\mathrm{r}=0.67,95 \% \mathrm{CI}=[0.27$, $0.88], \mathrm{t}=3.40, \mathrm{p}=0.004)$. There was no association between social ties and a composite measure of household wealth (Pearson's $r=$ $0.05,95 \% \mathrm{CI}=[-0.45,0.54], \mathrm{t}=0.21, \mathrm{p}=0.84)$. Across the two seasons, $67.8 \%$ of closely related households ( $\mathrm{s}>=0.25$ ) interacted compared to $39.3 \%$ of distantly related or unrelated households, proportions test: $X^{2}=35.3, \mathrm{p}<.001$; Fig. 4b).

If social interactions during periods of intense economic activity are in support of economic activities, then the off season in November-December represents a useful point of comparison. During the off season, individuals had interactions with members of fewer households, with interactions having occurred between $35 \%$ of households ( 84 of 240 ties). Even though the structure of the off-season network remained similar (average path length $=$ 1.59 transitivity $=0.58$ ), there was no association between the number of interactions per household between the fishing season months and the off season (dry season vs off-season: Pearson's $r$ $=-0.06,95 \% \mathrm{CI}=[-0.54,0.44], \mathrm{t}=-0.22, \mathrm{p}=0.8$; wet season $\mathrm{vs}$ off-season: Pearson's $\mathrm{r}=-0.18,95 \% \mathrm{CI}=[-0.62,0.33], \mathrm{t}=-0.18$, $\mathrm{p}=0.48)$.

Fig. 4. Social interactions between households in Barra do Sao Lorenço community. (a) Social network graphs of interactions between households across seasons. Circles are households, and edges represent interactions during the two weeks studied. Household order is the same in both graphs; (b) proportion of interactions between households that are kin (related by $\mathrm{s} \geq$ 0.25 ) or non-kin $(\mathrm{s}<0.25)$; (c) correlation between the number of interaction between households in each season.

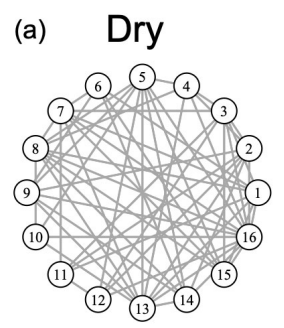

(b)

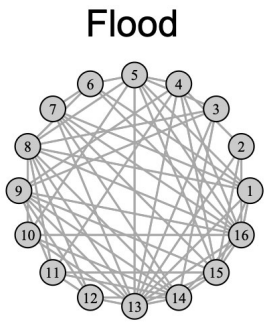

(c)
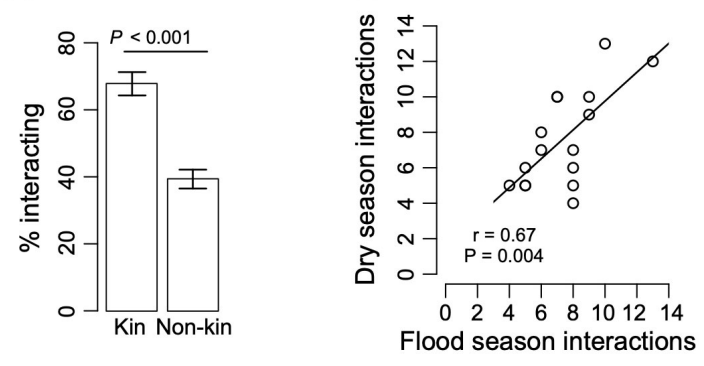

\section{DISCUSSION}

Our case study of the Pantanal fishers provides some important insights for resilience science and also for practitioners seeking to design conservation strategies in seasonal or changing ecosystems. First, we provide a quantitative portrait of economic resilience in the face of marked seasonal change in the Pantanal. We demonstrate that between the dry and wet seasons in 2019, the total amount of water accessible for fishing more than doubled, and almost quadrupled outside of the main river channel. The fishers in our study community dealt with this ecological change by altering their fishing techniques and target species and being more mobile in the flood, which allowed them to maintain similar fishing return rates between seasons. This is an important aspect of resilience in small-scale societies that conservation interventions tend to overlook (Song et al. 2018). Initiatives seeking sustainability of social-ecological systems often consider people as static agents in time and space (Wilson 2017) and, for fisheries, commonly seek to introduce measures such as forbidding certain fishing gear or the collection of certain species or sizes of fish, or restricting areas of use through the creation of strictly protected areas (Abbott and Campbell 2009). Such initiatives have been applied or suggested for the Barra do São Lourenço community (Chiaravalloti 2019) and many other fishery communities around the globe on several occasions in recent decades (Cooke et al. 2016). Our results suggest that if the fishers in our study community were restricted in their mobility 
or prohibited in the range of fishing gear they were permitted to use, they would not be able to adapt to the annual flood pulse, which can vary greatly in magnitude between years (Hamilton et al. 1996, Alho and Sabino 2012). This finding can be extrapolated to other seasonal ecosystems, like the Pantanal wetland, or regions that are currently facing more frequent environmental changes: limiting the ability of people to change their resource use strategies may hinder their resilience and may lead to poverty traps or community collapse (Béné 2009, Song et al. 2018).

We also studied the social network structure of our study community across fishing seasons and during the closed fishing season. We found that although the overall structure of interactions between households was reasonably stable between fishing seasons, interactions were significantly less frequent during the closed fishing season. We suggest that this is reflective of households relying less on one another for economic support and information sharing in the closed season. The social network analysis also showed that while some households had consistently more interactions than others, the distribution of these interactions (with the exception of interactions between closely related households) was relatively random and there was no correlation between the wealth and social connectedness of households. These results are indicative of a generally equal and autonomous political structure, which increases the chance of spreading the correct information about the location of fish or bait (Barnes et al. 2016). These social network results, combined with the economic and ecological data, provide a quantitative picture of this social-ecological system in which informationsharing and reciprocity are critical in dealing with the unpredictability of fishing and bait gathering in the Pantanal.

Many conservation interventions seeking to promote or evaluate good governance of social-ecological systems tend to underpin their approaches on common property regime (CPR) design principles (Ostrom 1990, Botto-Barrios and Saavedra-Díaz 2020). In other words, they are centered around the idea that clearly defined boundaries between people and the resources that they use play a pivotal role in communities' resilience (Dietz et al. 2003). This is indeed the case for many social-ecological systems. For instance, supported by the theory presented in Ostrom's Principles for CPRs, managers in the Mamirauá Sustainable Development Reserve, Amazon floodplains, implemented an arapiauma (Arapaima gigas) fishing program (Castello et al. 2009), which resulted in doubling increase of the arapaima population size and increased fishery revenues by $400 \%$ (CamposSilva and Peres 2016). However, in the Pantanal, the way community members found to control conflicting interests (collective-choice dilemma) and achieve social resilience was by having no boundaries between a certain number of people, instead of creating clear limits, named limited open access (Chiaravalloti and Dyble 2019). We argue that this may not only be seen in the Pantanal wetland, but in many seasonal ecosystems facing constant environmental changes, and other examples have already been presented in marine fisheries in Ecuador (Beitl 2015), swidden farming in Belize (Downey 2015), and pastoralists in Eastern Africa (Homewood and Rodgers 1991). Therefore, in seasonal ecosystems facing constant changes, actions should be focused on celebrating information exchange rather than imposing clear limits (Moritz et al. 2018).
It is important to emphasize that the flexibility in livelihood strategies and stability in social networks that we argue are an important aspect of community resilience do not necessarily lead to ecological sustainability (Holt 2005). Both have to match ecosystem dynamics (Ostrom 1990). However, that said, the region of the Barra do São Lourenço community has no sign of overfishing (Polaz et al. 2017). This is likely because of the variability of the flood pulse alongside the presence of moving floating vegetation that imposes natural barriers to fishers, making over $70 \%$ of the area inaccessible to fishing (Chiaravalloti and Dyble 2019). Similar ecological dynamics have been described for other social-ecological systems that present hybrid governance systems, such as pastoralists in East Africa who see over twothirds of the grassland in the region inaccessible (Scholte 2007, Homewood 2008). This allows regular refugia in which resources can increase populations in the absence of use, before being reconnected (Noy-Meir 1975, Berryman and Hawkins 2006). However, environmental changes and habitat destruction may well lead to major disruption of this social-ecological system. For example, climate change is predicted to drastically reduce the extent of the flood in the Pantanal (Thielen et al. 2020). Although our results show the ability of the community of Barra do São Lourenço to adapt to ecological variation, it is not guaranteed that customary strategies that are currently consistent with sustainability and resilience will continue to be effective in the face of these changes. Answers to these questions are necessary because they can support possible outside interventions that seek to protect both the well-being of local communities and ecosystem sustainability (Cooke et al. 2016).

\section{CONCLUSION}

We show seasonal differences in ecology, fishing practices, and social networks among fishers in the Brazilian Pantanal. We first use satellite data to quantify differences in the quantity of water accessible to fishers between the dry and flood seasons in 2019 , finding that accessible open water increases around four-fold outside of the main river channel. We show that while fishers adapt to this ecological change by changing their fishing strategies and increasing their mobility during the flood, the seasonal changes did not modify their networks of social interactions, which showed robustness in terms of information sharing and reciprocity. These results better clarify the internal dynamics of what we have previously characterized as a system of limited open access and emphasize the importance of looking quantitatively at multiple aspects of seasonal social-ecological change. We hope that our case study of adaptations to seasonal change can contribute to the building of a broader understanding of how communities adapt to social-ecological change and that this understanding can help to generate policy initiatives that help to protect thousands of local communities and ecosystems that they help protect (Garnett et al. 2018).

Responses to this article can be read online at: https://www.ecologyandsociety.org/issues/responses. php/12433 


\section{Acknowledgments:}

This study was part of the project "TIES - Trade-offs in Ecosystems and Socio Networks" funded by British Academy [NMGR1180519]. The authors are grateful to local people for their hospitality during field trips.

\section{Data Availability:}

All the dataset used in the paper, $r$ script and images created to analyze the data is available in Figshare at https://doi.org/10.60841 m9.figshare.11921253.v1, reference number 11921253.v1.

\section{LITERATURE CITED}

Abbott, J., and L. Campbell. 2009. Environmental histories and emerging fisheries management of the Upper Zambezi River Floodplains. Conservation and Society 7(2):83-99.

Alho, C. J. R., and J. Sabino. 2012. Seasonal Pantanal flood pulse: implications for biodiversity. Oecologia Australis 16(04):958-978. https://doi.org/10.4257/oeco.2012.1604.17

Allan, J. D., R. Abell, Z. Hogan, C. Revenga, B. W. Taylor, R. L. Welcomme, and K. Winemiller. 2005. Overfishing of inland waters. Bioscience 55(12):1041-1051. https://doi.org/10.1641/0006-3568 (2005)055[1041:OOIW]2.0.CO;2

Almeida, M. A. de, and C. J. da Silva. 2012. As Comunidades Tradicionais Pantaneiras Barra De São Lourenço e Amolar, Pantanal, Brasil. História e Diversidade 1(1):10-31.

Barnes, M. L., J. Lynham, K. Kalberg, and P. Leung. 2016. Social networks and environmental outcomes. Proceedings of the National Academy of Sciences 113(23):6466-6471. https://doi. org/10.1073/pnas.1523245113

Beitl, C. M. 2015. Mobility in the mangroves: catch rates, daily decisions, and dynamics of artisanal fishing in a coastal commons. Applied Geography 59:98-106. https://doi.org/10.1016/j.apgeog.2014.12.008

Béné, C. 2009. Are fisheries poor or vulnerable? Assessing economic vulnerability in small-scale fishing communities. Journal of Development Studies 45(6):911-933. https://doi. org/10.1080/00220380902807395

Benjaminsen, T., and C. Lund. 2002. Formalisation and informalisation of land and water rights in Africa: an introduction. European Journal of Development Research 14 (2):1-10. https://doi.org/10.1080/714000420

Berryman, A. A., and B. A. Hawkins. 2006. The refuge as an integrating concept in ecology and evolution. Oikos 115 (1):192-196. https://doi.org/10.1111/j.0030-1299.2006.15188.x

Bird, D. W., R. B. Bird, B. F. Codding, and D. W. Zeanah. 2019. Variability in the organization and size of hunter-gatherer groups: foragers do not live in small-scale societies. Journal of Human Evolution 131:96-108. https://doi.org/10.1016/j.jhevol.2019.03.005

Borras, S. M., and J. C. Franco. 2012. Global land grabbing and trajectories of agrarian change: a preliminary analysis. Journal of Agrarian Change 12(1):34-59. https://doi.org/10.1111/ j.1471-0366.2011.00339.x
Botto-Barrios, D., and L. M. M. Saavedra-Díaz. 2020. Assessment of Ostrom's social-ecological system framework for the comanagement of small-scale marine fisheries in Colombia: from local fishers' perspectives. Ecology and Society 25(1):12. https://doi.org/10.5751/es-11299-250112

Butts, C. T. 2008. Social network analysis: a methodological introduction. Asian Journal Of Social Psychology 11(1):13-41. https://doi.org/10.1111/j.1467-839X.2007.00241.X

Campos-Silva, J. V., and C. A. Peres. 2016. Community-based management induces rapid recovery of a high-value tropical freshwater fishery. Scientific Reports 6:34745. https://doi. org/10.1038/srep34745

Castello, L., J. P. Viana, G. Watkins, M. Pinedo-Vasquez, and V. A. Luzadis. 2009. Lessons from integrating fishers of arapaima in small-scale fisheries management at the Mamirauá Reserve, Amazon. Environmental Management 43:197-209. https://doi. org/10.1007/s00267-008-9220-5

Catella, A. C., S. P. Albuquerque, F. L. de R. Campos, and D. C. dos Santos. 2014. Sistema de Controle da Pesca de Mato Grosso do Sul SCPESCA/MS - 20 - 2013. Boletim de Pesquisa e Desenvolvimento 127:57.

Chiaravalloti, R. M. 2017a. Overfishing or over reacting? Management of fisheries in the Pantanal wetland, Brazil. Conservation and Society 15(1):111-122.

Chiaravalloti, R. M. 2017b. Systematic conservation planning in floodplain fisheries: to what extent are fishers' needs captured in prioritisation models? Fisheries Management and Ecology 24 (5):392-402. https://doi.org/10.1111/fme.12236

Chiaravalloti, R. M. 2019. The displacement of insufficiently "traditional" communities: local fisheries in the Pantanal. Conservation and Society 17(2):173-183.

Chiaravalloti, R. M., and M. Dyble. 2019. Limited open access in socioecological systems: how do communities deal with environmental unpredictability? Conservation Letters 12(2): e12616. https://doi.org/10.1111/conl.12616

Clark, J. K., and S. A. Crabtree. 2015. Examining social adaptations in a volatile landscape in northern Mongolia via the agent-based model Ger Grouper. Land 4(1):157-181. https://doi. org/10.3390/land4010157

Clark, W. C., and A. G. Harley. 2019. Sustainability science: towards a synthesis. Sustainability Science Program Working paper 2019-01. John F. Kennedy School of Government, Harvard University, Cambridge, Massachusetts, USA.

Cooke, S. J., E. H. Allison, T. D. Beard, R. Arlinghaus, A. H. Arthington, D. M. Bartley, I. G. Cowx, C. Fuentevilla, N. J. Leonard, K. Lorenzen, A. J. Lynch, V. M. Nguyen, S.-J. Youn, W. W. Taylor, and R. L. Welcomme. 2016. On the sustainability of inland fisheries: finding a future for the forgotten. Ambio 45 (7):753-764. https://doi.org/10.1007/s13280-016-0787-4

Costa, H. D. A., and S. Lucato. 2000. Coleta de iscas Vivas no Pantanal: Bases para a Sustentabilidade. Pages 1-24 III Simpósio sobre Recursos Naturais e Sócio-econômicos do Pantanal Os Desafios do Novo Milênio. Embrapa Pantanal, Brasil. 
Cowx, I. G., O. Almeida, C. Bene, R. Brummett, S. Bush, W. Darwall, J. Pittock, and M. van Brakel. 2004. Value of river fisheries. Pages 1-20 in R. L. Welcomme and T. Petr, editors. Proceedings of the Second International Symposium on the Management of Large Rivers for Fisheries. FAO Regional Office for Asia and the Pacific, Bangkok, Thailand.

Csardi, G., and T. Nepusz. 2006. The igraph software package for complex network research. InterJournal, Complex Systems 1695 (5):1-9.

Derry, J. F., and R. B. Boone. 2010. Grazing systems are a result of equilibrium and non-equilibrium dynamics. Journal of Arid Environments 74(2):307-309. https://doi.org/10.1016/j.jaridenv.2009.07.010

Dietz, T., E. Ostrom, and P. Stern. 2003. Struggle to govern the commons. Science 302(5652):1907-1912. https://doi.org/10.1126/ science. 1091015

Downey, S. S. S. 2015. Q'eqchi' Maya swidden agriculture, settlement history, and colonial enterprise in modern Belize. Ethnohistory 62(4):751-779. https://doi.org/10.1215/00141801-3135338

Dressler, W., B. Buscher, M. Schoon, D. Brockington, T. Hayes, C. A. Kull, J. MCcarthy, and K. Shrestha. 2010. From hope to crisis and back again? A critical history of the global CBNRM narrative. Environmental Conservation 37(01):5-15. https://doi. org/10.1017/S0376892910000044

Dyble, M., A. Gardner, L. Vinicius, and A. B. Migliano. 2018. Inclusive fitness for in-laws. Biology letters 14(10):20180515. https://doi.org/10.1098/rsbl.2018.0515

Dyble, M., J. Thompson, D. Smith, G. D. Salali, N. Chaudhary, A. E. Page, L. Vinicuis, R. Mace, and A. B. Migliano. 2016. Networks of food sharing reveal the functional significance of multilevel sociality in two hunter-gatherer groups. Current Biology 26(15):2017-2021. https://doi.org/10.1016/j.cub.2016.05.064

Dyble, M., J. Thorley, A. E. Page, D. Smith, and A. B. Migliano. 2019. Engagement in agricultural work is associated with reduced leisure time among Agta hunter-gatherers. Nature Human Behaviour 3(8):792-796. https://doi.org/10.1038/s41562-019-0614-6

Fa, J. E., J. E. M. Watson, I. Leiper, P. Potapov, T. D. Evans, N. D. Burgess, Z. Molnár, Á. Fernández-llamazares, T. Duncan, S. Wang, B. J. Austin, H. Jonas, C. J. Robinson, P. Malmer, K. K. Zander, M. V. Jackson, E. Ellis, E. S. Brondizio, and S. T. Garnett. 2020. Importance of Indigenous Peoples' lands for the conservation of intact forest landscapes. Frontiers in Ecology and the Environment 18(3):135-140. https://doi.org/10.1002/fee.2148

Folke, C., S. R. Carpenter, B. Walker, M. Scheffer, T. Chapin, and J. Rockström. 2010. Resilience thinking: integrating resilience, adaptability and transformability. Ecology and Society 15(4):20. https://doi.org/10.5751/ES-03610-150420

Garnett, S. T., N. D. Burgess, J. E. Fa, Á. Fernández-llamazares, Z. Molnár, C. J. Robinson, J. E. M. Watson, K. K. Zander, B. Austin, E. S. Brondizio, et al. 2018. A spatial overview of the global importance of Indigenous lands for conservation. Nature Sustainability 1:369-374. https://doi.org/10.1038/s41893-018-0100-6
Griggs, D., M. Stafford Smith, J. Rockström, M. C. Öhman, O. Gaffney, G. Glaser, N. Kanie, I. Noble, W. Steffen, and P. Shyamsundar. 2014. An integrated framework for sustainable development goals. Ecology and Society 19(4):49. https://doi. org/10.5751/ES-07082-190449

Hamilton, S. K., S. J. Sippel, and J. M. Melack. 1996. Inundation patterns in the Pantanal wetland of South America determined from passive microwave remote sensing. Archiv fur Hydrobiologie 137(1):1-23. https://doi.org/10.1127/archiv-hydrobiol/137/1996/1

Holt, F. L. 2005. The catch-22 of conservation: Indigenous peoples, biologists, and cultural change. Human Ecology 33 (2):199-215. https://doi.org/10.1007/s10745-005-2432-X

Homewood, K. 2008. Ecology of African pastoralist societies. James Currey, Oxford, UK.

Homewood, K., and W. A. Rodgers. 1991. Maasailand ecology: pastoralist development and wildlife conservation in Ngorongoro, Tanzania. Cambridge University Press, Cambridge, UK. https:// doi.org/10.1017/CBO9780511525568

Huang, M., and S. Jin. 2020. Rapid flood mapping and evaluation with a supervised classifier and change detection in Shouguang using Sentinel-1 SAR and Sentinel-2 optical data. Remote Sensing 12(13):2073. https://doi.org/10.3390/rs12132073

Intergovernmental Panel on Climate Change (IPCC). 2018. Global warming of $1.5^{\circ} \mathrm{C}$. An IPCC Special Report on the impacts of global warming of $1.5^{\circ} \mathrm{C}$ above pre-industrial levels and related global greenhouse gas emission pathways, in the context of strengthening the global response to the threat of climate change, sustainable development, and efforts to eradicate poverty. V. Masson-Delmotte, P. Zhai, H. O. Pörtner, D. Roberts, J. Skea, P. R. Shukla, A. Pirani, W. Moufouma-Okia, C. Péan, R. Pidcock, S. Connors, J. B. R. Matthews, Y. Chen, X. Zhou, M. I. Gomis, E. Lonnoy, T. Maycock, M. Tignor, and T. Waterfield, editors. In press.

Intergovernmental Science-Policy Platform on Biodiversity and Ecosystem Services (IPBES). 2019. Global assessment report on biodiversity and ecosystem services. IPBES, Bonn, Germany.

Junk, W. J., C. N. da Cunha, C. J. da Silva, and K. M. Wantzen. 2011. The Pantanal: a large South American wetland and its position in limnological theory. Pages 23-44 in W. J. Junk, C. J. D. A. Silva, C. N. Cunha, and K. M. Wantzen, editors. The Pantanal: ecology, biodiversity and sustainable management of a large neotropical seasonal wetland. Pensoft, Sofia, Bulgaria.

Junk, W. J., C. N. Da Cunha, K. M. Wantzen, P. Petermann, C. Strüssmann, M. I. Marques, and J. Adis. 2006. Biodiversity and its conservation in the Pantanal of Mato Grosso, Brazil. Aquatic Sciences 68(3):278-309. https://doi.org/10.1007/s00027-006-0851-4

Kelly, R. 2013. The lifeways of hunter-gatherers: the foraging spectrum. Cambridge University Press, Cambridge, UK. https:// doi.org/10.1017/CBO9781139176132

Laboratório de Aplicações de Satélites Ambientais (LASA). 2020. Área queimada Pantanal 2020. LASA, Rio de Janeiro, Brazil. 
Levin, S. A., and J. Lubchenco. 2008. Resilience, robustness, and marine ecosystem-based management. BioScience 58(1):27-32. https://doi.org/10.1641/b580107

Lewis, S. L., and M. A. Maslin. 2015. Defining the Anthropocene. Nature 519(7542):171-180. https://doi.org/10.1038/nature14258

Linkov, I., T. Bridges, F. Creutzig, J. Decker, C. Fox-lent, W. Kröger, J. H. Lambert, A. Levermann, B. Montreuil, J. Nathwani, R. Nyer, O. Renn, B. Scharte, A. Scheffler, M. Schreurs, and T. Thiel-clemen. 2014. Changing the resilience paradigm. Nature Climate Change 4(6):407-409. https://doi.org/10.1038/nclimate2227

Minter, T. 2010. The Agta of the Northern Sierra Madre. Dissertation. Lieden University, Leiden, The Netherlands.

Monk, C. T., M. Barbier, P. Romanczuk, J. R. Watson, J. Alós, S. Nakayama, D. I. Rubenstein, S. A. Levin, and R. Arlinghaus. 2018. How ecology shapes exploitation: a framework to predict the behavioural response of human and animal foragers along exploration-exploitation trade-offs. Ecology Letters 21(6):779-793. https://doi.org/10.1111/ele.12949

Moritz, M., R. Behnke, C. M. Beitl, R. Bliege Bird, R. M. Chiaravalloti, J. K. Clark, S. A. Crabtree, S. S. Downey, I. M. Hamilton, S. C. Phang, P. Scholte, and J. A. Wilson. 2018. Emergent sustainability in open property regimes. Proceedings of the National Academy of Sciences 115(51):12859-12867. https:// doi.org/10.1073/pnas.1812028115

Noy-Meir, I. 1975. Stability of grazing systems: an application of predator-prey graphs. Journal of Ecology 63(2):459-481. https:// doi.org/10.2307/2258730

Ostrom, E. 1990. Governing the commons. Cambridge University Press, Cambridge, UK.

Ostrom, E. 2007. A diagnostic approach for going beyond panaceas. Proceedings of the National Academy of Sciences 104 (39):15181-15187. https://doi.org/10.1073/pnas.0702288104

Polaz, C. N. M., F. C. Ferreira, and M. Petrere Júnior. 2017. The protected areas system in Brazil as a baseline condition for wetlands management and fish conservancy: the example of the Pantanal National Park. Neotropical Ichthyology 15(3). https:// doi.org/10.1590/1982-0224-20170041

Pott, V. J., A. Pott, L. C. P. Lima, S. N. Moreira, and A. K. M. Oliveira. 2011. Aquatic macrophyte diversity of the Pantanal wetland and upper basin. Brazilian Journal of Biology $=$ Revista Brasleira de Biologia 71(1 Suppl 1):255-263. https://doi. org/10.1590/S1519-69842011000200004

Pyhälä, A., A. Orozco, and S. Counsell. 2019. Protected areas in the Congo Basin: failing both people and biodiversity? Rainforest Foundation, London, UK.

R Core Team. 2018. R: A Language and Environment for Statistical Computing. Vienna, Austria.

Ribot, J. C., and N. L. Peluso. 2009. A theory of access. Rural Sociology 68(2):153-181. https://doi.org/10.1111/j.1549-0831.2003. $\underline{\text { tb00133.x }}$

Robinson, B. E., Y. J. Masuda, A. Kelly, M. B. Holland, C. Bedford, M. Childress, D. Fletschner, E. T. Game, C. Ginsburg,
T. Hilhorst, S. Lawry, D. A. Miteva, J. Musengezi, L. NaughtonTreves, C. Nolte, W. D. Sunderlin, and P. Veit. 2018. Incorporating land tenure security into conservation. Conservation Letters 11 (2):e12383. https://doi.org/10.1111/conl.12383

Scholte, P. 2007. Maximum flood depth characterizes aboveground biomass in African seasonally shallowly flooded grasslands. Journal of Tropical Ecology 23:63-72. https://doi. org/10.1017/S026646740600366X

Sikor, T., and C. Lund. 2009. Access and property: a question of power and authority. Development and Change 40(1):1-22. https:// doi.org/10.1111/j.1467-7660.2009.01503.X

Soille, P., and P. Vogt. 2009. Morphological segmentation of binary patterns. Pattern Recognition Letters 30(4):456-459. https://doi.org/10.1016/j.patrec.2008.10.015

Song, A. M., S. D. Bower, P. Onyango, S. J. Cooke, S. L. Akintola, J. Baer, T. B. Gurung, M. Hettiarachchi, M. Islam, W. Mhlanga, F. Nunan, P. Salmi, V. Singh, X. Tezzo, S. J. Funge-Smith, P. K. Nayak, and R. Chuenpagdee. 2018. Intersectorality in the governance of inland fisheries. Ecology and Society 23(2):17. https://doi.org/10.5751/ES-10076-230217

Thielen, D., K. L. Schuchmann, P. Ramoni-Perazzi, M. Marquez, W. Rojas, J. I. Quintero, and M. I. Marques. 2020. Quo vadis Pantanal? Expected precipitation extremes and drought dynamics from changing sea surface temperature. PLoS ONE 15(1): e0227437. https://doi.org/10.1371/journal.pone.0227437

Thomas, M. G., M. W. Næss, B. J. Bårdsen, and R. Mace. 2015. Saami reindeer herders cooperate with social group members and genetic kin. Behavioral Ecology 26(6):1495-1501. https://doi. org/10.1093/beheco/arv106

Tomas, W. M., F. de Oliveira Roque, R. G. Morato, P. E. Medici, R. M. Chiaravalloti, F. R. Tortato, J. M. F. Penha, T. J. Izzo, L. C. Garcia, R. F. F. Lourival, P. Girard, N. R. Albuquerque, M. Almeida-Gomes, M. H. da S. Andrade, F. A. S. Araujo, A. C. Araujo, E. C. de Arruda, V. A. Assunção, L. D. Battirola, M. Benites, F. P. Bolzan, J. C. Boock, I. M. Bortolotto, M. da S. Brasil, A. R. Camilo, Z. Campos, M. A. Carniello, A. C. Catella, C. C. Cheida, P. G. Crawshaw, S. M. A. Crispim, G. A. D. Junior, A. L. J. Desbiez, F. A. Dias, D. P. Eaton, G. P. Faggioni, M. A. Farinaccio, J. F. A. Fernandes, V. L. Ferreira, E. A. Fischer, C. E. Fragoso, G. O. Freitas, F. Galvani, A. S. Garcia, C. M. Garcia, G. Graciolli, R. D. Guariento, N. M. R. Guedes, A. Guerra, H. M. Herrera, R. Hoogesteijn, S. C. Ikeda, R. S. Juliano, D. L. Z. K. Kantek, A. Keuroghlian, A. C. R. Lacerda, A. L. R. Lacerda, V. L. Landeiro, R. R. Laps, V. Layme, P. Leimgruber, F. L. Rocha, S. Mamede, D. K. S. Marques, M. I. Marques, L. A. F. Mateus, R. N. Moraes, T. A. Moreira, G. M. Mourão, R. D. Nicola, D. G. Nogueira, A. P. Nunes, C. da Nunes da Cunha, M. D. Oliveira, M. R. Oliveira, G. M. Paggi, A. O. Pellegrin, G. M. F. Pereira, I. A. H. F. S. Peres, J. B. Pinho, J. O. P. Pinto, A. Pott, D. B. Provete, V. D. A. dos Reis, L. K. dos Reis, P.-C. Renaud, D. B. Ribeiro, O. C. Rossetto, J. Sabino, D. Rumiz, S. M. Salis, D. J. Santana, S. A. Santos, Â. L. Sartori, M. Sato, K.-L. Schuchmann, E. ScreminDias, G. H. F. Seixas, F. Severo-Neto, M. R. Sigrist, A. Silva, C. J. Silva, A. L. Siqueira, B. M. A. Soriano, L. M. Sousa, F. L. Souza, C. Strussmann, L. S. M. Sugai, N. Tocantins, C. Urbanetz, F. Valente-Neto, D. P. Viana, A. Yanosky, and W. J. Junk. 2019. 
Sustainability agenda for the Pantanal Wetland: perspectives on a collaborative interface for science, policy, and decision-making. Tropical Conservation Science 12:1-30. https://doi. org/10.1177/1940082919872634

Vogt, P., and K. Riitters. 2017. GuidosToolbox: universal digital image object analysis. European Journal of Remote Sensing 50 (1):352-361. https://doi.org/10.1080/22797254.2017.1330650

Walker, B., C. S. Holling, S. R. Carpenter, and A. Kinzig. 2004. Resilience, adaptability and transformability in social-ecological systems. Ecology and Society 9(2):5. https://doi.org/10.5751/ ES-00650-090205

Whitfield, S., E. Beauchamp, D. S. Boyd, D. Burslem, A. Byg, F. Colledge, M. E. J. Cutler, M. Didena, A. Dougill, G. Foody, J. A. Godbold, M. Hazenbosch, M. Hirons, C. Ifejika Speranza, E. Jew, C. Lacambra, D. Mkwambisi, A. Moges, A. Morel, R. Morris, P. Novo, M. Rueda, H. Smith, M. Solan, T. Spencer, A. Thornton, J. Touza, and P. C. L. White. 2019. Exploring temporality in socio-ecological resilience through experiences of the 2015-16 El Niño across the tropics. Global Environmental Change 55:1-14. https://doi.org/10.1016/j.gloenvcha.2019.01.004

Wilson, J. 2017. Learning, adaptation, and the complexity of human and natural interactions in the ocean. Ecology and Society 22(2):43. https://doi.org/10.5751/ES-09356-220243

Winemiller, K. O., P. B. McIntyre, L. Castello, E. FluetChouinard, T. Giarrizzo, S. Nam, I. G. Baird, W. Darwall, N. K. Lujan, I. Harrison, M. L. J. Stiassny, R. A. M. Silvano, D. B. Fitzgerald, F. M. Pelicice, A. A. Agostinho, L. C. Gomes, J. S. Albert, E. Baran, M. Petrere, C. Zarfl, M. Mulligan, J. P. Sullivan, C. C. Arantes, L. M. Sousa, A. A. Koning, D. J. Hoeinghaus, M. Sabaj, J. G. Lundberg, J. Armbruster, M. L. Thieme, P. Petry, J. Zuanon, G. T. Vilara, J. Snoeks, C. Ou, W. Rainboth, C. S. Pavanelli, A. Akama, A. V. Soesbergen, and L. Saenz. 2016. Balancing hydropower and biodiversity in the Amazon, Congo, and Mekong. Science 351(6269):128-129. https://doi.org/10.1126/ $\underline{\text { science.aac7082 }}$

Xu, H. 2006. Modification of normalised difference water index (NDWI) to enhance open water features in remotely sensed imagery. International Journal of Remote Sensing 27 (14):3025-3033. https://doi.org/10.1080/01431160600589179 